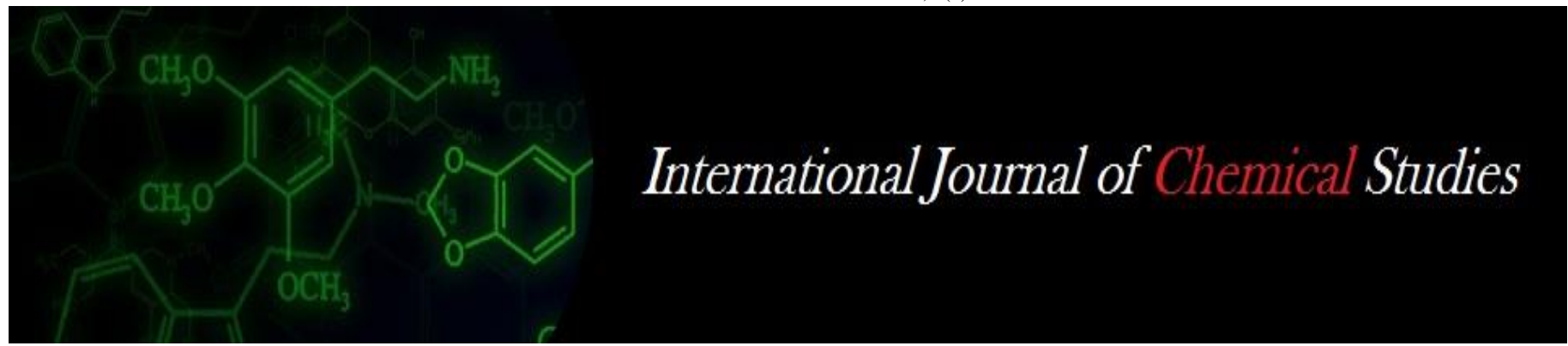

P-ISSN: 2349-8528

E-ISSN: 2321-4902

www.chemijournal.com

IJCS 2020; 8(6): 829-833

(C) 2020 IJCS

Received: 21-08-2020

Accepted: 06-10-2020

Kiran SK

Student, University of

Agricultural Sciences, Bangalore,

Karnataka, India

Prakash SS

Professor and Head, University

of Agricultural Sciences,

Bangalore, Karnataka, India

Chamegowda TC

Professor, University of

Agricultural Sciences, Bangalore,

Karnataka, India

Krishnamurthy $\mathbf{R}$

Associate Professor, University

of Agricultural Sciences,

Bangalore, Karnataka, India

Yogananda SB

Associate Professor, University

of Agricultural Sciences,

Bangalore, Karnataka, India

Asha NN

Assistant Professor, University of Agricultural Sciences,

Bangalore, Karnataka, India
Corresponding Author:

Kiran SK

Student, University of

Agricultural Sciences, Bangalore,

Karnataka, India

\section{Root and yield paramters of maize as influenced by application of different biostimulants in Alfisols of Karnataka}

\author{
Kiran SK, Prakash SS, Chamegowda TC, Krishnamurthy R, Yogananda \\ SB and Asha NN
}

\section{DOI: $\underline{\text { https://doi.org/10.22271/chemi.2020.v8.i6l.10873 }}$}

\begin{abstract}
A field experiment was conducted to evaluate the performance of maize upon applicaton of different biostimulants namely, humic caid extracted from FYM, Spirulina algal extract and microbial consortia in red soils of zone 6 of Karnataka during Kharif 2018 on sandy loam soil at college of Agriculture, V.C. Farm, Mandya. The experiment was laid out in RCBD with thirteen treatments including control, $100 \%$ RDF, $100 \%$ RDF + microbial consortia (MC), 100\% RDF + MC + humic acid @ 0.25 and $0.50 \%, 100 \%$ RPP + MC + algal extract @ 10 and 20\% and the above treatments were repeated with 75\% RPP. Results revealed that application of biostimulants had a significant effect on growth and yield of maize. Application of $100 \%$ RPP along with biostimulants had significant effect on yield parameters, root parameters and yield of maize. Higher root length, shoot length, root: shoot, yield parameters like cob length, number of rows per cob, number of kernels per row and test weight was higher in $\mathrm{T}_{7}$ treatment receiving 100\% RPP along with microbial consortia and $20 \%$ algal extract. Treatment $\mathrm{T}_{7}$ recorded significantly higher grain and stover yield of 81.67 and $89.79 \mathrm{q} \mathrm{ha}^{-1}$, respectively.
\end{abstract}

Keywords: Biostimulant, Humic acid, Algal extract, Microbial consortia.

\section{Introduction}

The continuous use of fertilizers in the crop cultivation i.e., showed some deleterious effect on soil quality and environment. Biologically and biochemically mediated processes in soils are of utmost importance to ecosystem function and these functions were under threat in the modern production system. Maintanence of soil health is very important for the biochemical processes including the transformation of organic matter (Miltner et al., 2011) ${ }^{[8]}$, nutrient release (Wichern et al., 2007) ${ }^{[19]}$ and degradation of xenobiotics. The scientists have started recommending firstly the use of organic manure along with chemical fertilizers, secondly completely organic farming techniques and thirdly use of biostimulants to increase the efficiency of nutrient utilization and tolerance to abiotic stress, improve the quality of crops and microbial diversity. Among the above mentioned practices, biostimulant in crop production is recently gaining lot of importance as the most sustainable and viable technology for the producers who are looking for the production of quality produce at the same time without causing undue stress on soil resources.

Biostimulants are either natural or synthetic organic substances containing hormones or precursors of plant hormones, when applied in lower concentration to soil or seed (seed coating) or plant (foliar spray) favour the growth of the plant by improving the vital physiological processes of the crop allowing higher yields and quality produce. Besides, biostimulants enhances the nutrition efficiency, abiotic tolerance and soil biological functions. As a significance of these reported benefits, biostumulants have sparked attention with many crop producers in the recent years. With increasing awareness of benefits of organically produced products, the demand for these are increasing in the market.

The role of biostimulants in improving the yield and quality of the crop produce and soil properties though not clearly demonstrated as these are composed of number of components as ingredient. However, the literature pertaining to the topic indicate that the yield increase and enhanced quality of the crop might be due to improvement in the efficiency of plants' 
metabolism, increase in plant tolerance and resilience from abiotic stress, improvement in nutrient assimilation/translocation/use, increasing water use efficiency and enhanced soil fertility by fostering the development of complimentary soil microbial community. It means most of biostiumulants improves plant's vigour and do not have any direct actions against pests or diseases and as a source of nutrients, regardless of the presence of nutrients in the products. These biostimulants improve plant nutrition by affecting soil processes and by directly affecting the plant's physiology.

In the present study spirulina algal extract, humic acid extracted from FYM and microbial consortia were used to study the response of maize.

\section{Material and methods}

Field experiment was conducted during Kharif 2018 on at College of Agriculture, Vishweshwaraiah Canal (V. C.) Farm, Mandya, Karnataka. The experiment consists of 13 treatment combinations as mentioned below

Treatment details

\begin{tabular}{|c|c|c|c|}
\hline Treatment & Details & Treatment & Details \\
\hline $\mathrm{T}_{1}$ & Control & $\mathrm{T}_{8}$ & $75 \%$ RPP \\
\hline $\mathrm{T}_{2}$ & $100 \%$ RPP & $\mathrm{T}_{9}$ & $75 \% \mathrm{RPP}+\mathrm{MC}$ \\
\hline $\mathrm{T}_{3}$ & $100 \% \mathrm{RPP}+\mathrm{MC}$ & $\mathrm{T}_{10}$ & $75 \% \mathrm{RPP}+\mathrm{MC}+\mathrm{HA} 0.25 \%$ \\
\hline $\mathrm{T}_{4}$ & $100 \%$ RPP + MC + HA @ $0.25 \%$ & $\mathrm{~T}_{11}$ & $75 \%$ RPP + MC + HA $0.50 \%$ \\
\hline $\mathrm{T}_{5}$ & $100 \%$ RPP + MC + HA @ $0.50 \%$ & $\mathrm{~T}_{12}$ & $75 \% \mathrm{RPP}+\mathrm{MC}+\mathrm{AE} @ 10 \%$ \\
\hline $\mathrm{T}_{6}$ & $100 \%$ RPP + MC + AE @ 10\% & $\mathrm{T}_{13}$ & $75 \% \mathrm{RPP}+\mathrm{MC}+\mathrm{AE} @ 20 \%$ \\
\hline $\mathrm{T}_{7}$ & $100 \% \mathrm{RPP}+\mathrm{MC}+\mathrm{AE} @ 20 \%$ & & \\
\hline
\end{tabular}

NOTE: $\quad$ MC-Microbial consortia HA-Humic acid $\quad$ AE-Algal extract $\quad$ RPP-Recommended package of practices as per the UAS B package of practices includes application of Recommended dose of NPK for Maize is 150:75:40 $\mathrm{kg} \mathrm{ha}^{-1}+10 \mathrm{~kg} \mathrm{ha}^{-1} \mathrm{ZnSO}_{4}$, with farm yard manure (FYM) at the rate of $10 \mathrm{tha}^{-1}$.

The microbial consortia was applied to soil along with FYM i.e. at 15 days before sowing of maize. While, humic acid and algal extract was foliar sprayed at 30 and 45 days after sowing.

\section{Extraction of humic substances}

Humic acid was extracted from well decomposed FYM by alkaline extraction method and further acidification as described by Stevenson (1981) ${ }^{[16]}$. Five $\mathrm{kg}$ of air dried FYM was weighed and transferred to plastic container to which 25 liters of $0.5 \mathrm{~N} \mathrm{NaOH}$ was added and the contents were shaken for 24 hours (Schnitzer and Skinner, 1968) ${ }^{[12]}$. The dark coloured supernatant solution was separated by filtration and collected. Then the supernatant was acidified and centrifuged to obtain humic acid. Precipitation and centrifugation was repeated to attain partial purification of humic acid fraction. Then it was placed in oven and dried at $60{ }^{\circ} \mathrm{C}$ to a constant weight. The humic acid obtained was ground and diluted to get the required concentration.

\section{Microbial consortia}

Microbial consortia consisting of $\mathrm{N}$ - fixer (Azotobacter chrococcum $)+\mathrm{P}-$ solubilizer (Bacillus megaterium) $+\mathrm{K}-$ solubilizer (Frateuria aurantia) + Pseudomonas fluorescens + Trichoderma viridae was obtained from Biofertilizer Unit, University of Agricultural Sciences, Bangalore and applied to soil along with FYM (15 days before sowing) at the rate of 2 $\mathrm{kg}$ per acre.

\section{Production of the algal extract}

The mother culture of Spirulina platensis was obtained from Center for Conservation and Utilization of Blue green Algae, IARI, New Delhi. Two ml of mother culture was inoculated into media broth to get sub-cultures for future use. Fifty $\mathrm{ml}$ culture was mixed initially with $500 \mathrm{ml}$ zorrouck's medium ( $\mathrm{pH} 10)$. The culture was kept in an orbital shaker with natural illumination (3000 lux) and temperature of $30^{\circ} \mathrm{C}$ for 7 days. Using the subcultures, the mass production has been carried out to obtain spirulina algal mass. The extract obtained was smashed in pestle and mortar and the solution was considered as 100 per cent. The solution was further diluted to get required concentration.

Table 1: Initial Physico-chemical properties of soil at the experimental site

\begin{tabular}{|c|c|c|c|}
\hline Sl. No & Parameter & Method & Value \\
\hline \multicolumn{4}{|c|}{ Physical Properties } \\
\hline 1 & Sand $(\%)$ & \multirow{4}{*}{ International pipette method } & 80.51 \\
\hline 2 & Silt $(\%)$ & & 9.14 \\
\hline 3 & Clay $(\%)$ & & 9.23 \\
\hline 4 & Textural class & & Sandy loam \\
\hline 5 & Bulk density $\left(\mathrm{Mg} \mathrm{m}^{-3}\right)$ & & 1.51 \\
\hline \multicolumn{4}{|c|}{ Chemical properties } \\
\hline 1 & $\mathrm{pH}(1: 2.5)$ & Potentiometry & 7.21 \\
\hline 2 & $\mathrm{EC}_{2.5}\left(\mathrm{dS} \mathrm{m}^{-1}\right)$ & Conductometry & 0.17 \\
\hline 3 & Organic carbon $\left(\mathrm{g} \mathrm{kg}^{-1}\right)$ & Wet digestion & 5.70 \\
\hline$\frac{3}{4}$ & Available N $\left(\mathrm{kg} \mathrm{ha}^{-1}\right)$ & Alkaline potassium permanganate distillation method & 276.87 \\
\hline$\frac{4}{5}$ & Available $\mathrm{P}_{2} \mathrm{O}_{5}\left(\mathrm{~kg} \mathrm{ha}^{-1}\right)$ & Olsens extractant method, Colorimetry & 35.33 \\
\hline 6 & Available $\mathrm{K}_{2} \mathrm{O}\left(\mathrm{kg} \mathrm{ha}^{-1}\right)$ & Ammonium acetate extractant method, Flame photometry & 260.80 \\
\hline 7 & Available $\mathrm{Ca}\left(\mathrm{cmol}\left(\mathrm{p}^{+}\right) \mathrm{kg}^{-1}\right)$ & \multirow{2}{*}{ Ammonium acetate extractant method, Versenate titration method } & 4.71 \\
\hline 8 & Available $\mathrm{Mg}\left(\mathrm{cmol}\left(\mathrm{p}^{+}\right) \mathrm{kg}^{-1}\right)$ & & 3.13 \\
\hline 9 & Available $\mathrm{S}\left(\mathrm{mg} \mathrm{kg}^{-1}\right)$ & $\mathrm{CaCl}_{2}$ extraction, Turbidimetry & 14.72 \\
\hline 10 & DTPA Fe $\left(\mathrm{mg} \mathrm{kg}^{-1}\right)$ & \multirow{4}{*}{ Atomic absorption spectrophotometry } & 12.76 \\
\hline 11 & DTPA Zn $\left(\mathrm{mg} \mathrm{kg}^{-1}\right)$ & & 0.79 \\
\hline 12 & DTPA Mn $\left(\mathrm{mg} \mathrm{kg}^{-1}\right)$ & & 7.94 \\
\hline 13 & DTPA Cu $\left(\mathrm{mg} \mathrm{kg}^{-1}\right)$ & & 0.61 \\
\hline 14 & Hot water soluble Boron $\left(\mathrm{mg} \mathrm{kg}^{-1}\right)$ & Hot water extraction method and colorimetry using Azomethine-H & 0.51 \\
\hline
\end{tabular}


The soil at the experimental site was sandy loam in texture with $80.51,9.14$, and 9.23 per cent sand, silt and clay, respectively and bulk density of soil was $1.51 \mathrm{Mg} \mathrm{m}^{-3}$. The soil was neutral in reaction $(\mathrm{pH} 7.21)$ and low in soluble salts $\left(0.17 \mathrm{dS} \mathrm{m}^{-1}\right)$. The soil was medium in organic carbon $(5.70 \mathrm{~g}$ $\left.\mathrm{kg}^{-1}\right)$, low in available nitrogen (276.87 $\mathrm{kg} \mathrm{ha}^{-1}$ ), medium in available $\mathrm{P}_{2} \mathrm{O}_{5}$ (35.33 $\mathrm{kg} \mathrm{ha}^{-1}$ ), medium in available $\mathrm{K}_{2} \mathrm{O}$ (260.80 kg ha $\left.{ }^{-1}\right)$ and sufficient in sulphur (14.72 $\left.\mathrm{mg} \mathrm{kg}^{-1}\right)$. The exchangeable calcium and magnesium content of soil was 4.71 and $3.13 \mathrm{c} \mathrm{mol} \mathrm{kg}^{-1}$, respectively. The content of DTPA extractable iron, zinc, manganese, copper and hot water soluble boron was $12.76,0.79,7.94,0.61$ and $0.51 \mathrm{mg} \mathrm{kg}^{-1}$, respectively.

\section{Results and discussion}

Table 2: Root parameters at 60 DAS as influenced by application of different biostimulant

\begin{tabular}{|c|c|c|c|}
\hline Treatments & $\begin{array}{c}\text { Root dry weight } \\
(\mathbf{g})\end{array}$ & $\begin{array}{c}\text { Shoot dry weight } \\
(\mathbf{g})\end{array}$ & Root: Shoot \\
\hline $\mathrm{T}_{1}$ & 16.85 & 75.46 & 0.22 \\
\hline $\mathrm{T}_{2}$ & 19.05 & 96.10 & 0.20 \\
\hline $\mathrm{T}_{3}$ & 19.92 & 96.74 & 0.21 \\
\hline $\mathrm{T}_{4}$ & 21.87 & 97.16 & 0.23 \\
\hline $\mathrm{T}_{5}$ & 22.01 & 97.92 & 0.22 \\
\hline $\mathrm{T}_{6}$ & 23.47 & 98.16 & 0.24 \\
\hline $\mathrm{T}_{7}$ & 24.18 & 98.82 & 0.24 \\
\hline $\mathrm{T}_{8}$ & 18.68 & 90.12 & 0.21 \\
\hline $\mathrm{T}_{9}$ & 18.71 & 91.07 & 0.21 \\
\hline $\mathrm{T}_{10}$ & 19.08 & 92.12 & 0.21 \\
\hline $\mathrm{T}_{11}$ & 19.86 & 92.73 & 0.21 \\
\hline $\mathrm{T}_{12}$ & 20.11 & 94.48 & 0.21 \\
\hline $\mathrm{T}_{13}$ & 20.82 & 95.32 & 0.22 \\
\hline $\mathrm{S.Em} \pm$ & 0.92 & 4.21 & 0.01 \\
\hline $\mathrm{CD} @ 5 \%$ & 2.67 & $\mathrm{NS}$ & 0.03 \\
\hline \multicolumn{2}{|r|}{}
\end{tabular}

Table 3: Yield attributes of maize as affected by application of different biostimulants

\begin{tabular}{|c|c|c|c|c|}
\hline Treatments & $\begin{array}{c}\text { Cob length } \\
\text { (cm) }\end{array}$ & $\begin{array}{c}\text { No. of rows } \\
\text { per cob }\end{array}$ & $\begin{array}{c}\text { Kernels per } \\
\text { row }\end{array}$ & $\begin{array}{c}\text { Test } \\
\text { weight }\end{array}$ \\
\hline $\mathrm{T}_{1}$ & 12.10 & 11.50 & 21.90 & 25.57 \\
\hline $\mathrm{T}_{2}$ & 17.80 & 15.65 & 27.13 & 30.03 \\
\hline $\mathrm{T}_{3}$ & 18.00 & 15.70 & 27.97 & 30.19 \\
\hline $\mathrm{T}_{4}$ & 18.40 & 15.95 & 28.17 & 30.51 \\
\hline $\mathrm{T}_{5}$ & 18.40 & 16.15 & 28.30 & 30.79 \\
\hline $\mathrm{T}_{6}$ & 18.80 & 16.53 & 31.00 & 31.07 \\
\hline $\mathrm{T}_{7}$ & 19.10 & 16.67 & 31.30 & 31.20 \\
\hline $\mathrm{T}_{8}$ & 16.90 & 14.53 & 24.80 & 28.43 \\
\hline $\mathrm{T}_{9}$ & 17.00 & 14.67 & 25.85 & 28.60 \\
\hline $\mathrm{T}_{10}$ & 17.20 & 14.87 & 26.01 & 28.97 \\
\hline $\mathrm{T}_{11}$ & 17.30 & 15.10 & 26.23 & 29.16 \\
\hline $\mathrm{T}_{12}$ & 17.93 & 15.47 & 26.65 & 29.73 \\
\hline $\mathrm{T}_{13}$ & 18.27 & 15.63 & 27.07 & 29.95 \\
\hline $\mathrm{S} . \mathrm{Em} \pm$ & 0.78 & 0.68 & 1.22 & 1.32 \\
\hline $\mathrm{CD}$ @ 5\% & 2.28 & 1.99 & 3.56 & $\mathrm{NS}$ \\
\hline
\end{tabular}

Table 4: Kernel and stover yield $\left(\mathrm{q} \mathrm{ha}^{-1}\right)$ as affected by application of different biostimulants in maize

\begin{tabular}{|c|c|c|}
\hline Treatments & Kernel yield $\left(\mathbf{q} \mathbf{h a}^{-\mathbf{1}}\right)$ & Stover yield $\left(\mathbf{q} \mathbf{h a}^{-\mathbf{1}}\right)$ \\
\hline $\mathrm{T}_{1}$ & 41.12 & 45.39 \\
\hline $\mathrm{T}_{2}$ & 71.59 & 80.41 \\
\hline $\mathrm{T}_{3}$ & 73.28 & 81.36 \\
\hline $\mathrm{T}_{4}$ & 77.16 & 86.19 \\
\hline $\mathrm{T}_{5}$ & 78.24 & 87.01 \\
\hline $\mathrm{T}_{6}$ & 80.86 & 88.57 \\
\hline $\mathrm{T}_{7}$ & 81.67 & 89.79 \\
\hline $\mathrm{T}_{8}$ & 62.89 & 71.87 \\
\hline
\end{tabular}

\begin{tabular}{|c|c|c|}
\hline $\mathrm{T}_{9}$ & 63.97 & 72.09 \\
\hline $\mathrm{T}_{10}$ & 66.03 & 74.91 \\
\hline $\mathrm{T}_{11}$ & 67.30 & 76.04 \\
\hline $\mathrm{T}_{12}$ & 70.14 & 78.91 \\
\hline $\mathrm{T}_{13}$ & 71.03 & 80.73 \\
\hline S.Em \pm & 3.06 & 3.48 \\
\hline CD @ 5\% & 8.94 & 10.16 \\
\hline
\end{tabular}

\section{Root dry weight}

The root dry weight at 60 DAS as influenced by application of biostimulants is indicated in Table 2. Higher root dry weight of $24.18 \mathrm{~g}$ was recorded in $\mathrm{T}_{7}(100 \% \mathrm{RPP}+\mathrm{MC}+$ $20 \%$ AE) which was on par with $\mathrm{T}_{4}(21.87 \mathrm{~g}), \mathrm{T}_{5}(22.01 \mathrm{~g})$ and $\mathrm{T}_{6}(23.19 \mathrm{~g})$ and significant with all other treatments. Lower root dry weight of $16.85 \mathrm{~g}$ was recorded in control.

\section{Shoot dry weight}

At 60 DAS, the data of shoot dry weight varied significantly due to treatments. The shoot dry weight in control was 75.46 $\mathrm{g}$ which increased significantly to $98.82 \mathrm{~g}$ in treatment $\mathrm{T}_{7}$ $(100 \% \mathrm{RPP}+\mathrm{MC}+20 \% \mathrm{AE})$ which was on par with all the treatments except control.

\section{Root: shoot}

The root: shoot varied significantly due to treatments and indicated in Table 2.

Root to shoot ratio indicated that, significantly higher root to shoot ratio was recorded in $\mathrm{T} 6$ and $\mathrm{T}_{7}(0.24)$ which received $100 \% \mathrm{RPP}+\mathrm{MC}+\mathrm{AE}$ and was on par with all other treatments except $\mathrm{T} 2(0.20)$.

Higher root dry weight and root to shoot ratio was observed in biostimulants applied treatments than that of treatments having fertilizer alone. Biostimulants are known to have a crucial role in altering the root physiology which might be attributed to activity of hormones, which triggers root proliferation with higher root length, root branching and root hair density and thereby higher nutrient absorption capacity of the plant.

These results are in conformity with those reported by Chen and Aviad (1990) ${ }^{[3]}$, who have reported that application of HA derived from vermicompost increased lateral-root proliferation and elongation in maize. They attributed this effect to the auxin-like activity of HS, which stimulates plasma membrane $\mathrm{H}^{+}$-ATPase, thereby stimulating cellular growth. Similar improvement in root density of maize with application of humic acid was reported by Chen and Aviad (1990) ${ }^{[3]}$ and algal extract by Canellas et al. (2002) ${ }^{[2]}$ and Sharif et al. (2006) ${ }^{[14]}$. An increase in root proliferation, lateral-root and root-hair development increases the surface area of the root, which would explain the increased nutrient uptake induced by biostimulants application.

\section{Yield Parameters}

The data with respect to cob length, number of rows per cob, kernels per row and test weight are indicated in Table 3.

\section{Cob length (cm)}

The experimental data indicated that, significantly higher cob length of $19.10 \mathrm{~cm}$ was recorded in $\mathrm{T}_{7}$ compared to control $(12.10 \mathrm{~cm}) . \mathrm{T} 7$ treatment was on par with all other treatments except control.

\section{Number of rows per cob}

The data on number of rows per cob as influenced by the application of biostimulants are presented in Table 3 . 
Number of rows per cob varied significantly due to imposition of treatments. Least number of rows per cob was recorded in control (11.50) which increased significantly to 16.67 in $\mathrm{T}_{7}$ due to application of 100 per cent RPP + microbial consortia +20 per cent algal extract. But the number of rows per cob recorded in $\mathrm{T}_{7}$ was statistically at par with all the treatments except $\mathrm{T}_{1}, \mathrm{~T}_{8}$ and $\mathrm{T}_{9}$.

\section{Kernels per row}

Significantly higher number of kernels per row was recorded in $\mathrm{T}_{7}$ (31.30) (100\% RPP + MC $\left.+20 \% \mathrm{AE}\right)$ which was on par with treatments receiving $100 \%$ RPP with either of the biostimulants and significant with rest of the treatments. Lowest number of kernels per row was recorded in control (21.90).

\section{Test weight $(\mathrm{g})$}

As indicated in Table 3, test weight did not vary significantly. The data indicated that, higher test weight of $31.20 \mathrm{~g}$ was recorded in $\mathrm{T}_{7}$ and lowest test weight was recorded in control $(25.57 \mathrm{~g})$.

The observed increase in yield parameters with the application of biostimulants (HA, AE and MC) along with NPK fertilizer might be attributed to improvement in growth parameters. Application of biostimulants have a major role in improving the plant vigour and higher nutrient absorption which results in improved source to sink relationship. Thus increase in yield parameters may be attributed to efficient translocation of photosynthates and availability of adequate amount of nutrients (Harshad et al., 2013) [7], enhanced photosynthetic rate, better nutrient uptake from the soil and increased accumulation and translocation of metabolites or nutrients (Shahmaleki et al. (2014) ${ }^{[13]}$. Zodape et al. (2009) ${ }^{[19]}$ reported that the increase in growth and yield attributes in crops with the application of biostimulants might be due to presence of some growth promoting substances such as IAA and IBA, gibberellins, cytokinin, micronutrients, vitamins and amino acids in the biostimulants. Similar response in yield parameters upon application of biostimulants were recorded by Ebrahimpour et al. (2011) ${ }^{[4]}$, Fatma et al. (2014) ${ }^{[5]}$ and Tejada et al. (2018) ${ }^{[16]}$ in maize.

\subsubsection{Kernel and stover yield $\left(q \mathrm{ha}^{-1}\right)$}

The data on kernel and stover yield of maize as influenced by application of graded levels of HA and SAE are presented in Tables 4.

The kernel and stover yield of maize varied significantly with the application of $\mathrm{HA}$ and SAE along with chemical fertilizers. The data indicated that, kernel yield of $81.67 \mathrm{q} \mathrm{ha}^{-1}$ recorded in $\mathrm{T}_{7}$ treatment $(100 \% \mathrm{RPP}+\mathrm{MC}+20 \% \mathrm{AE})$ was significantly higher than that recorded in control (41.12 $\mathrm{q}$ ha $\left.{ }^{1}\right)$ and $\mathrm{T}_{2}\left(71.59 \mathrm{q} \mathrm{ha}^{-1}\right)$ and it was on par with all other treatments.

In case of stover yield, treatment $\mathrm{T}_{7}(100 \% \mathrm{RPP}+\mathrm{MC}+20 \%$ AE) recorded higher stover yield of $89.79 \mathrm{q} \mathrm{ha}^{-1}$ which was on par with treatments receiving $100 \%$ RPP and $\mathrm{T}_{13}(80.73 \mathrm{q}$ ha $\left.{ }^{1}\right)$.

The yield of crop is a manifestation of growth and yield parameters of crop and environmental conditions. Thus the higher yield recorded in the present investigation with $T_{7}$ treatment $\left(82.20 \mathrm{q} \mathrm{ha}^{-1}\right)$ was due to higher growth parameters, yield parameters and nutrients uptake recorded in the treatment. The yield obtained with foliar application of humic acid $(0.25$ and $0.50 \%)+\mathrm{MC}+$ fertilizers $(100$ and $75 \%)$ was giving on par results with that of treatments receiving foliar application of algal extract. Biostimulants might have facilitated the acquisition of nutrients by supporting metabolic processes in plants such as cell division, expansion of cell wall, meristematic activity, enzymatic activity, photosynthetic efficiency which contributed for the observed higher kernel and stover yield of maize. The improved metabolic process in the plants was due to the presence of amino acids and hormones present in the biostimulants.

The positive response of maize to humic acid application with respect to grain and stover yield was evidenced by Reza and Moghadam et al. (2014) ${ }^{[10]}$, Sharif et al. (2006) ${ }^{[14]}$, Verlinden et al. (2011) ${ }^{[17]}$ and to algal extract application by Gaurav Kumar [6] and Dinabandhu Sahoo, $2011^{[6]}$, Fatma et al. (2014) ${ }^{[5]}$, Andrade et al. (2018) ${ }^{[1]}$, Safinaz and Ragaa (2013) ${ }^{[11]}$ and Nofal et al. (2016) ${ }^{[9]}$.

\section{References}

1. Andrade LM, Dias M, Claudio AON. Performance of maize seedlings using biostimulant in seed treatment. Cientifica 2018;46(3):274-282.

2. Canellas LP, Leonardo BD, Silva C. Humic acids crossinteractions with root and organic acids. Ann Appl Biol 2002;153(2):157-166.

3. Chen Y, Aviad T. Effects of humic substances on plant growth. J Pl Nutri 1990;32:1407-1426.

4. Ebrahimpour F, Eidizadeh KH, Damghani AM. Sustainable nutrient management in maize with integrated application of biological and chemical fertilizers. Int J Agric Sci 2011;1:423-426.

5. Fatma MA, Ragaa A, Hamouda, Ammar MM. The promotive effect of different concentrations of marine algae biofertilizers on growth and yield of maize (Zea mays L.) plants. J Chem Bio Phy Sci 2014;4(3):25-32.

6. Gaurav Kumar, Dinabandhu Sahoo. Effect of seaweed liquid extract on growth and yield of Triticum aestivum var. Pusa Gold. J Appl Phycol 2011;23:251-255.

7. Harshad T, Bhanurekha K, Sudhakara SN, Padmaja G. Effect of humic substances on growth and yield of sunflower (Helianthus annuus L.). J Res ANGRAU 2013;41(4):106-108.

8. Miltner A, Petra B, Matthias K. SOM Genesis: Microbial biomass as a significant source. Biogeochem 2011;111(13):1-15.

9. Nofal O, Hellal F, Bakry BA. Response of peanut and maize crops to foliar application of algae extracts under sandy soil condition. Res J Pharmaceutical Biol Chem Sci 2016;7(5):151-157.

10. Reza H, Moghadam T. Humic acid as an ecological pathway to protect corn plants against oxidative stress. Biol Forum - An Int J 2014;7(1):1704-1709.

11. Safinaz AF, Ragaa AH. Effect of some red marine algae as biofertilizers on growth of maize (Zea mays L.) plants. Int Food Res J 2013;20(4):1629-1632.

12. Schnitzer M, Skinner SIM. Alkali versus acid extraction of soil organic matter. Soil Sci 1968;105:392-396.

13. Shahmaleki SK, Golam AP, Mahmood G. Acid humic foliar application affects fruit quality characteristics of tomato. Agric Sci Dev 2014;3(10):312-316.

14. Sharif M, Khattak RA, Sarir MS. Effect of different levels of lignitic coal derived humic acid on growth of maize plants. Commun Soil Sci Pl Anal 2006;33:35673580 .

15. Stevenson FJ. Humus Chemisty, Genesis, Composition and Reactions, Wiley Interscience Pub., John Wiley and Sons. Inc., New York 1981, P26-54. 
16. Tejada M, Bruno RM, Patricia P, Parrado J. Effects of foliar fertilization of a biostimulant obtained from chicken feathers on maize yield. European J Agron 2018;96:54-59.

17. Verlinden G, Pyckemertens BJ, Debersaques F, Verheyen K, Baert G, Bries J, Haesaert G. Application of humic substances results in consistent increases in crop yield and nutrient uptake. J PI Nutr 2011;32:1407-1426.

18. Wicherna F, Mayerb J, Rainer Geor J, Torsten M. Release of $\mathrm{C}$ and $\mathrm{N}$ from roots of peas and oats and their availability to soil microorganisms. Soil Biol Biochem 2007;39:2829-2839.

19. Zodape ST, Mukherjee S, Reddy MP, Chaudhary DR. Effect of Kappaphycus alvarezii (Doty) extract on grain quality, yield and some yield components of wheat (Triticum aestivum L.). Int J Pl Prodn 2009;3(2):97-101. 